\title{
Selection and Characterization of Some Essential Oils for the Treatment of Medical Furs
}

\begin{abstract}
OLGA NICULESCU*, LUMINITA ALBU ${ }^{1}$, MARIA CARMEN LOGHIN², CARMEN GAIDAU ${ }^{1}$, LUCRETIA MIU1', GHEORGHE COARA ${ }^{1}$ ${ }^{1}$ National Research and Development Institute for Textiles and Leather - Division Leather and Footwear Research Institute, 93 Ion Minulescu Str., 031215, Bucharest, Romania

${ }^{2}$ Gheorghe Asachi Technical University of lasi, Faculty of Textile - Leather and Industrial Management, 29 Dimitrie Mangeron Str., 700050, Iasi, Romania

It is now increasingly accepted that medicinal plants can be successfully used to treat certain conditions. There are a large number of people with rheumatic, joint and muscular disorders, and it is necessary to improve the treatment of patients suffering from these conditions byalternative methods. For these diseases, phytotherapy recommends plant species with analgesic, antiseptic, anti-inflammatory effects, etc. The paper refers to obtaining and their characterization by physico-chemical analyses new products based on natural oils (cajeput and mint essential oils), ethyl alcohol, non-ionogenic surfactants from the category of polyethoxylated fattyalcohols and polyethylene glycols and water, for the treatment of medical furs. Cajeput and mint essential oils used to obtain new products was analysed using GC-MS and spectral analyses. The composition of cajeput essential oil analyzed by GC-MS indicates the presence of the following major compounds: Eucalyptol -57.02\%, alpha-linalool-2.93\%, alpha-pinene-2.77\%. The composition of mintessential oil analyzed by GC-MS indicates the presence of the following major compounds: Menthol $-40.04 \%$, Lmenthone $-23.78 \%$, I-Menthone $-14.51 \%$. The furs will be used to make natural fur articles for medical purposes (lumbar belts, ankle guards, bootees etc.) to relieve rheumatic and muscular pain of the affected targetareas, keeping the area warm and potentiating the medical treatment of the patients who suffer from these conditions.
\end{abstract}

Keywords: cajeput essential oil, mint essential oil, FT-IR spectrometry, Gas Chromatography Mass Spectrometry (GC/MS), furs for medical use

The improvement of natural fur processing technologies is closely related to chemical auxiliaries used in various operations to improve processing efficiency or to delay or prevent the occurrence of undesirable phenomena that affect the quality of natural furs and fur articles.

In fur processing technologies, finishing can be carried out in two ways: by treatments in the float and by pressing the hair, typically after setting out and fixing the hairs in order to obtain some special effects.[1,2]

Heatcan relieve rheumatic pain (transmitted by applying natural fur).

Sanitation of medical furs was made using the essential oils, with therapeutic effect, in the final treatment of tanned furs.

Many species of herbs containing essential oils bring their contribution all over the world in preventing various diseases.

The development of synthetic substances has replaced almost $80 \%$ of the therapeutic arsenal, herbal medicines being replaced by chemical synthesis, but a multitude of adverse effects were found that disrupt the body's adaptive mechanisms.

The fact that living organisms have not been programmed to accept other substances than those which nature produces specifically for the benefit of all living beings has been so far ignored.

It is now increasingly accepted that herbs can be successfully used in treating certain diseases.

Essential oils are oily, water-insoluble, alcohol- and organic solvent-soluble liquids with a characteristic odor of the volatile substances they contain $[3,4]$.
Essential oils are known for their particular scent and their therapeutic qualities [5-15].

The antioxidant, antimicrobial, antifungal, anticarcinogenic, immunostimulatory, sedative, flavoring properties demonstrated by the many studies conducted in recent years on the composition of essential oils make them important in areas such as the chemical, food, pharmaceutical, perfumery industries, and last, but not least, in agriculture and medicine. Volatile oil properties are directly related to their composition, both qualitatively and quantitatively.

Current studies focus on the development and optimization of analytical methods able to determine the composition of these oils (chromatographic fingerprint), and identify certain compounds that attest to the quality and authenticity of the products $[16,17]$.

This paper presents characterization of the cajeput and mint essential oils by gas chromatography coupled with mass spectroscopy - GC-MS and FT-IR spectrometry, and the process of obtaining and physical-chemical characterization of new products based on cajeput and mintessential oils, ethyl alcohol, non-ionogenic surfactants from the category of polyethoxylated fatty alcohols and polyethylene glycols, and cationic surfactants (quaternary ammonium salts), for the treatment of medical furs.

Sheepskins (Merinos) were tanned (non-metallic tanning) with syntans based on phenolsulphonic acids and aromatic oxisulfones, [18-20] and in the final finishing phase were treated with products based on essential oils with therapeutic properties (analgesic, anti-inflammatory and relaxing). Sanitation of medical furs was made using cajeput and mint essential oils, with therapeutic effect.

* email: o_niculescu@yahoo.com 


\section{Experimental part}

Materials and methods

- Cajeput oil (Adams, Romania), containing 57.02\%

eucaliptol, 2.93\% alpha-linalool, $2.93 \%$ alpha-linalool, $2.77 \%$ caryophillene etc.;

- Mintoil (Adams, Romania), containing 40.04\% menthol, $23.78 \%$ I-menthone, $14.51 \%$ i-menthone, $4.24 \%$ menthyl acetate etc.;

- Ethanol (Chemical Company, Germany), colorless liquid, boiling point $78.37^{\circ} \mathrm{C}$, density $-0.79 \mathrm{~g} / \mathrm{cm}^{3}$;

- Nonionic emulsifier - lauryl alcohol ethoxylated with 7 moles of ethylene oxide (Elton Corporation, Romania), density $-0.95 \mathrm{~g} / \mathrm{cm}^{3}$ at $40^{\circ} \mathrm{C}, \mathrm{pH}$ ( $10 \%$ solution) - 7-8;

- Polyethylene Glycol 400 (Merck, Germany), density $1.13 \mathrm{~g} / \mathrm{cm}^{3}$ at $20^{\circ} \mathrm{C}$, flash point $>200^{\circ} \mathrm{C} ; \mathrm{pH}$ ( $10 \%$ solution) $5-7$; melting point $-5^{\circ} \mathrm{C}$, ignition temperature $-360^{\circ} \mathrm{C}$;

- Hexadecyl-trimethyl ammonium bromide (Merck, Germany), water solubility of $3 \mathrm{~g} / \mathrm{L}, \mathrm{pH}$ ( $10 \%$ solution) $-5-7$, melting point $237-243^{\circ} \mathrm{C}$, hygroscopic;

- Product made from cajeput essential oil: dry substance - $19-20 \%$, pH ( $10 \%$ solution) - 4-4.5, density $-0.900-0.920 \mathrm{~g} /$ $\mathrm{cm}^{3}$;

- Product made from mint essential oil: dry substance $20-21 \%, p H$ (10\% solution) $-4-4.5$, density $-0.890-0.900 \mathrm{~g} /$ $\mathrm{cm}^{3}$;

- Sheepskins tanned with syntans based on phenolsulphonic acids and aromatic oxisulfones (National Research and Development Institute for Textiles and Leather - Division Leather and Footwear Research Institute Bucharest, Romania).

Synthesis of materials based on plant extracts for biological protection and fragrance of fur was conducted in a glass flask using a heating and homogenization installation (Velp) and an ultrasonic bath (Elmasonic S 15 H).

Attenuated Total Reflectance Fourier transform infrared spectroscopy (ATR-FTIR) measurements were run with a Jasco instrument (model 4200), in the following conditions: wavenumber range $-600-4000 \mathrm{~cm}^{-1}$; data pitch -0.964233 $\mathrm{cm}^{-1}$; data points -3610: aperture setting -7.1 mm; scanning speed $-2 \mathrm{~mm} / \mathrm{s}$; number of scans -30 ; resolution $-4 \mathrm{~cm}^{-1}$; filter $-30 \mathrm{kHz}$; angle of incident radiation $-45^{\circ}$.

Gas Chromatography Mass Spectrometry (GC/MS) Analysis:

Analysis of the essential oils was carried out by using Agilent 7890 A GC System equipped with Agilent 5795 C MS, and HP-5 MS $(0.25 \mathrm{~mm} \times 30 \mathrm{~m}$ i.d., film thickness $0.25)$. The carried gas helium (99.9\%) at a flow rate of 1 $\mathrm{mL} / \mathrm{min}$; ionization energy was $70 \mathrm{eV}$. Mass range $\mathrm{m} / \mathrm{z} 50$ 650 amu. Data acquisition was scan mode. MS transfer line temperature was $250^{\circ} \mathrm{C}$, MS Ionization source temperature was $230^{\circ} \mathrm{C}$, the injection port temperature was $250^{\circ} \mathrm{C}$. The samples were injected with 250 split ratio. The injection volume was $1 \mu \mathrm{L}$. Oven temperature was programmed in the range of 50 to $250^{\circ} \mathrm{C}$ at $3^{\circ} \mathrm{C} / \mathrm{min}$. The structure of each compound was identified by comparison with their mass spectrum (Nist 05 and Wiley 7 library) [17].

\section{Obtaining product based on cajeput and mint essential oils}

The following components were added to the mixing vessel: $60 \%$ cajeput (or $60 \%$ mint) essential oil, $10 \%$ ethyl alcohol, 10\% lauric alcohol ethoxylate with seven moles of ethylene oxide, $8 \%$ polyethylene glycol 400 (nonionogenic), $1 \%$ hexadecyltrimethylammonium bromide (cationic) and $11 \%$ deionized water. Components were homogenised using a mechanical stirrer, on an electrically heated installation, at the temperature of $30-35^{\circ} \mathrm{C}$, for 15 $20 \mathrm{~min}$. In order to homogenise components, an ultrasound bath was used, in which the glass flask was inserted, at the temperature of $25^{\circ} \mathrm{C}$, for $10 \mathrm{~min}$. 21-24]

\section{Results and discussions}

Characterisation of components used to obtain products

Cajeput and mint essential oils used to obtain products were analysed using GC-MS and FT-IR. Chromatogram for cajeput and mint oils is shown in figure 1 and 2 , and identification of compounds in their composition is presented in table 1 and 2.

The following compounds are found in the highest amount: Eucaliptol - 57.02\%, alpha-terpineol -19.46\%, alpha-linalool $-2.93 \%$, alpha-pinene $-2.77 \%$ and caryophillene $-2.77 \%$.

The following compounds are found in the highest amount: Menthol $-40.04 \%$, L-menthone $-23.78 \%$, Imenthone $-14.51 \%$, D-limonene $-8.51 \%$ and menthyl acetate $-4.24 \%$.

FT-IR (ATR) spectra of cajeput and mint essential oils are shown in figure 3 and 4.

The main bands of cajeput oil are (fig. 3): $3471 \mathrm{~cm}^{-1}$ indicating the presence of hydroxyl groups, 2965 and 2922 $\mathrm{cm}^{-1}$-indicating the presence of aliphatic $\mathrm{CH}_{2}$ groups, 1643 $\mathrm{cm}^{-1}$ - indicating the presence of $\mathrm{C}=0$ group from ester, 1462 and $1375 \mathrm{~cm}^{-1}$-assigned to the $\mathrm{C}-\mathrm{H}$ group, $1214 \mathrm{~cm}$ ${ }^{1}$ and $982 \mathrm{~cm}^{-1}$ given by the $\mathrm{C}-0$ group from ether.

The main bands of mint oil are (fig. 4): $3423 \mathrm{~cm}^{-1}$ indicating the presence of hydroxyl groups, $2921 \mathrm{~cm}^{-1}$. indicating the presence of aliphatic $\mathrm{CH}_{2}$ groups, $1707 \mathrm{~cm}$ ${ }^{1}$-indicating the presence of $\mathrm{C}=0$ group from ester, 1452 and $1369 \mathrm{~cm}^{-1}$-assigned to the $\mathrm{C}-\mathrm{H}$ group, $1246 \mathrm{~cm}^{-1}$ and $885 \mathrm{~cm}^{-1}$ given by the $\mathrm{C}-0$ group from ether.

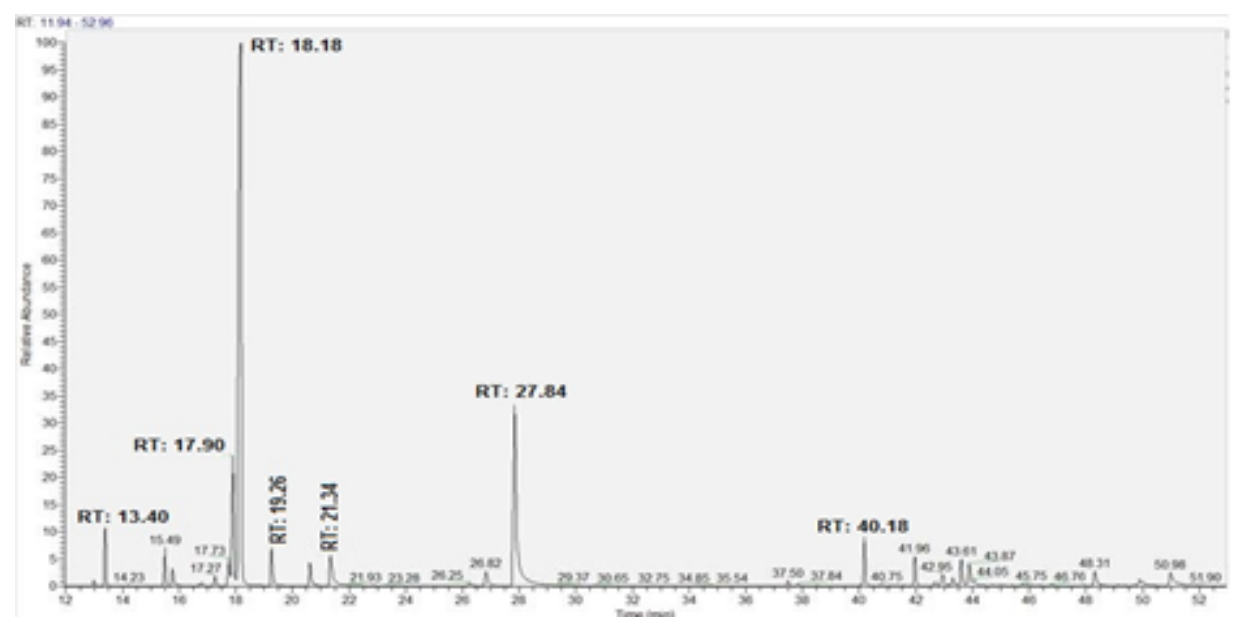

Fig.1. Chromatogram of organic compounds in the cajeput oil 
Table 1

IDENTIFICATION OF ORGANIC COMPOUNDS IN THE CAJEPUT ESSENTIAL OIL BY GC-MS

\begin{tabular}{|c|c|c|c|}
\hline No. & RT & Amount, $\%$ & Compounds \\
\hline 1 & 13.4 & 2.77 & alpha-pinene \\
\hline 2 & 15.49 & 1.73 & 2-alpha-pinene \\
\hline 3 & 18.18 & 57.02 & Eucaliptol \\
\hline 4 & 19.26 & 2.38 & gama-terpinene \\
\hline 5 & 20.61 & 1.66 & alpha-terpinolene \\
\hline 6 & 21.34 & 2.93 & alpha-linalool \\
\hline 7 & 26.82 & 1.36 & 4-terpineol \\
\hline 8 & 27.84 & 19.46 & alpha-terpineol \\
\hline 9 & 40.18 & 2.77 & caryophillene \\
\hline 10 & 41.96 & 1.85 & alpha-humulene \\
\hline 11 & 43.61 & 1.66 & alpha-selinene \\
\hline 12 & 43.87 & 1.43 & alpha-selinene \\
\hline 13 & 48.31 & 1.30 & Guaiol \\
\hline 14 & 50.98 & 1.68 & alpha-eudesmol \\
\hline
\end{tabular}

Table 2

IDENTIFICATION OF ORGANIC COMPOUNDS IN THE MINT ESSENTIAL OIL BY GC-MS

\begin{tabular}{|c|c|c|c|}
\hline No. & RT & Amount, $\%$ & Compounds \\
\hline 1 & 13.4 & 4.03 & alpha-pinene \\
\hline 2 & 15.49 & 3.59 & 2-a-pinene \\
\hline 3 & 17.88 & 8.51 & D-limonene \\
\hline 4 & 24.62 & 1.30 & isopulegol \\
\hline 5 & 25.21 & 23.78 & L-menthone \\
\hline 6 & 25.82 & 14.51 & I-menthone \\
\hline 7 & 26.66 & 40.04 & Menthol \\
\hline 8 & 33.14 & 4.24 & menthyl acetate \\
\hline
\end{tabular}

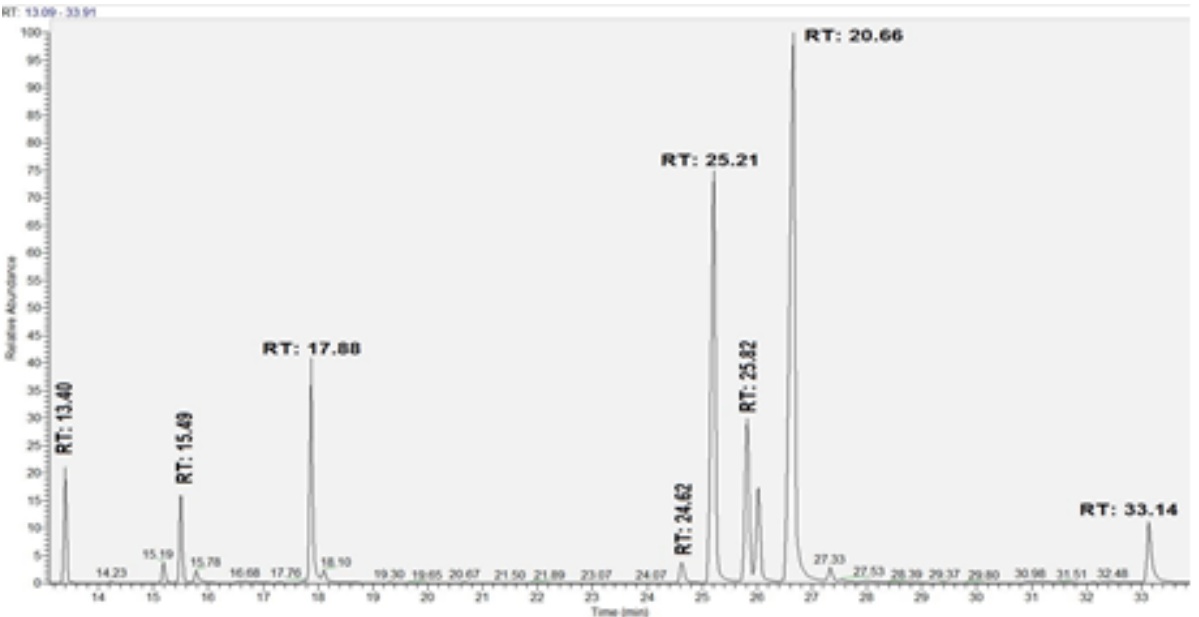

Fig.2. Chromatogram of organic compounds in the mint oil

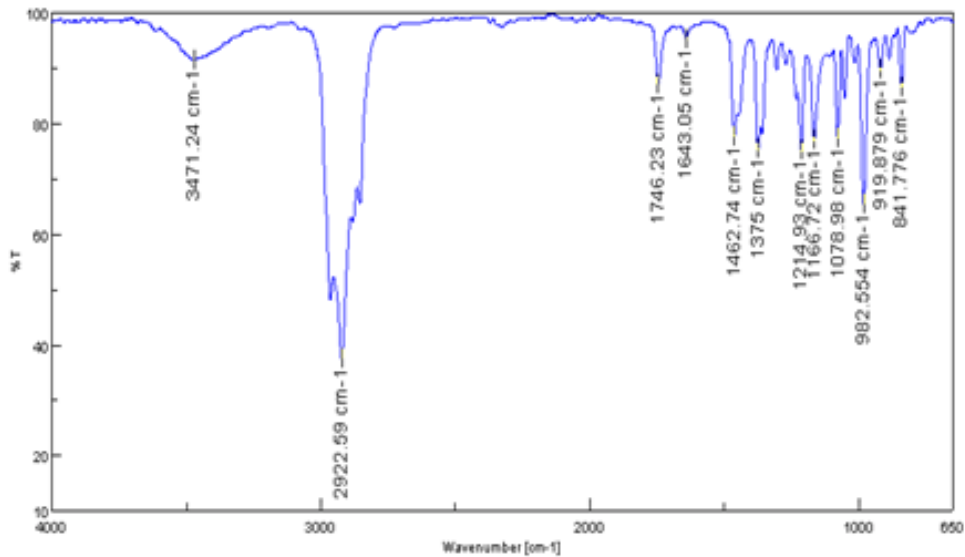

Fig. 3. FT-IR spectra of cajeput essential oil

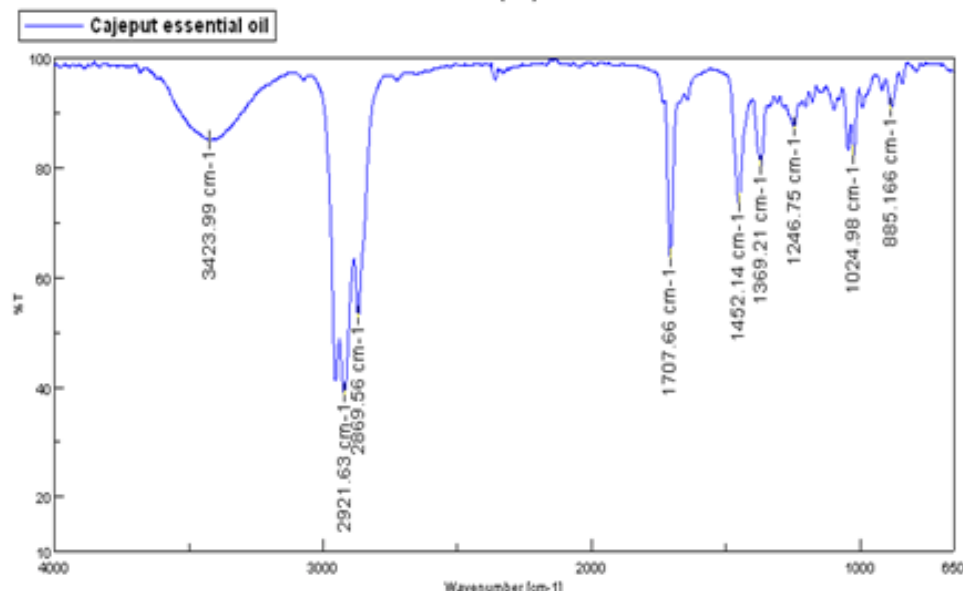

Fig. 4. FT-IR spectra of mint essential oil 
Physico-chemical characteristics of products based on essential oils

The prepared products, P-CAJ is yellowish white fluid, homogenous, with $19-20 \%$ dry substance, $\mathrm{pH}-4.0-4.5$, density $-0.900-0.920 \mathrm{~g} / \mathrm{cm}^{3}$, and P-MIN is yellowish white fluid, homogenous, with $20-21 \%$ dry substance, $\mathrm{pH}-4.0$ 4.5, density $-0.890-0.900 \mathrm{~g} / \mathrm{cm}^{3}$.

Chemical characteristics of products based on essentials oils were determined according to the following standards: dry substance (\%) -SR EN ISO 4684:2006; $p H$ SR-EN ISO 4098: 2006.

\section{Characterisation of fur assortments obtained}

Product preparations - P-CAJ - contain $60 \%$ cajeput essential oil, $10 \%$ ethyl alcohol, $10 \%$ lauric alcohol ethoxylate with seven moles of ethylene oxide, $8 \%$ polyethylene glycol 400 (non-ionogenic), 1\% hexadecyltrimethylammonium bromide (cationic) and $11 \%$ deionized water.

Product preparations - P-MIN - contain $60 \%$ mint essential oil, 10\% ethyl alcohol, 10\% lauric alcohol ethoxylate with seven moles of ethylene oxide, $8 \%$ polyethylene glycol 400 (non-ionogenic), 1\% hexadecyltrimethylammonium bromide (cationic) and $11 \%$ deionized water.

The following were determined Chromium VI content undetectable values for furs assortments obtained.

Chemical characteristics of the Merinos furs were determined according to the following standards: the content of chromium oxide (\%) -SR EN ISO 17075:2008.

The obtained products can be applied to Merinos sheep fur in two ways:

- in the float as a final operation using 20-30\% essential oil based products in $100 \%$ water bath at $50-60^{\circ} \mathrm{C}$ in the presence of a biodegradable nonionic emulsifier, ethoxylated lauryl alcohol with 7 moles of ethylene oxide ( $10 \%$ of the amount of product used) for $30 \mathrm{~min}$.

- by dabbing with a cloth on the fur or fur articles.

Treatment with these products can be repeated at certain time intervals, and the application procedure on the fur surface or fur articles is easy.

Fur articles treated with the developed products, in a proportion of $30 \%$, are more effective than those treated with the same products in a proportion of $20 \%$.

Eucalyptol, the ingredient in the composition of cajeput oil, with analgesic and disinfectant properties, are effective in the treatment of patients suffering from rheumatism, lumbar radiculopathy and cervical spondylosis, stimulating blood circulation and relieving rheumatic and joint pain.

Menthol, the ingredient in the composition of peppermint oil, stimulates receptors signaling the cold sensation and inhibits receptors reacting to pain stimuli, temporarily relieving muscle pain.

The products can be used to treat the surface of finished sheep furskins (free of metals) for medical purposes and improve the quality of natural fur and fur articles (lumbar belts, ankle guards, bootees etc.) used to prevent, relieve and treat rheumatic, muscular, circulatory disorders, complementing the medical treatment of patients suffering from these conditions, keeping the fur-covered area warm.

The treatment of each person varies depending on their general health, allergies, age and gender.

\section{Conclusions}

The prepared products, P-EUC and P-MIN, is yellowish white fluid, homogenous, with $19-21 \%$ dry substance, $\mathrm{pH}$ 4.0-4.5, density $-0.890-0.920 \mathrm{~g} / \mathrm{cm}^{3}$.

The P-CAJ and P-MIN products with therapeutic properties (analgesic, anti-inflammatory and relaxing) can be used (in proportion of 20-30\%) for treatment of medical furs.

Sheepskins were be tanned with syntans based on phenolsulphonic acids and aromatic oxisulfones.

The products can be used to treat the surface of finished sheep furskins (free of metals) for medical purposes and improve the quality of natural fur and fur articles (lumbar belts, ankle guards, bootees etc.) used to prevent, relieve and treat rheumatic, muscular, circulatory disorders, complementing the medical treatment of patients suffering from these conditions, keeping the fur-covered area warm.

Acknowledgment: This article is funded by the Ministry of Research and Innovation within Program 1 - Development of the national RD system, Subprogram 1.2 - Institutional Performance - RDI excellence funding projects, Contract no. 6PFE/ 16.10.2018.

\section{References}

1. CHIRITA, Gh., CHIRITA, M., Tratat de chimia si tehnologia pieilor si blanurilor, vol. I, Ed. Gh. Asachi, lasi 1999.

2. MAIER,S.S., Tehnologia prelucrarii blanurilor. Note de curs, Universitatea Tehnica Gh. Asachi din laoi, 2008.

3. *** Farmacopeea Romana, editia a X-a, Ed. Medicala, Bucuresti, 1998.

4. *** European Pharmacopeia, vol. II, ESCOP Strasbourg, Council of Europe, 2005.

5. CIULEI, I., GRIGORESCU, E., STANESCU, U., Plante medicinale, fitochimie si fitoterapie, vol. 2, Ed. Medicala, Bucuresti, 1993.

6. PALADE, M., Botanica farmaceutica, Ed. Tehnica, Bucure-ti, 1998. 7. PARVU, C., Enciclopedia plantelor. Plante din flora Romaniei, Bucure-ti, Editura Tehnicã, 2002.

8. CONSTANTINESCU, D.G., HATIEGANU, E., BUSURICU, F., Plante medicinale utilizate in terapeutica, Bucuresti, Editura Medicala, 2004. 9. STANESCU, U., MIRON, A., HANCIANU, M., APROTOSOAIE, C., Plante medicinale de la A la Z, lasi , Editura Gr. T. Popa, 2004.

10. ARDELEAN, A., MOHAN, G., Flora medicinala a Romaniei, Bucuresti, Editura All, 2008.

11. ISTUDOR, V., Farmacognozie, Fitochimie, Fitoterapie, vol. I, Ed. Medicala, Bucuresti, 1998.

12. TRIFUNSCHI, S., MUNTEANU, M.F., POGURSCHI, E., GLIGOR, R., Characterisation of Polyphenolic Compounds in Viscum album L. and Allium sativum L. Extras, Rev. Chim. (Bucharest), 68, no. 7, 2017, p.1677.

13. VARUT, R. M., ROTARU, L.T., Determination of Polyphenol and Flavonoid Profiles and Testing the Antibacterial Effect of Acanthus longifolius Comparative with Vaccinium Myrtillus, Rev. Chim. (Bucharest), 68, no. 7, 2017, p.1419.

14. JURCA, T., MARIAN, E., TITA, B., VICAS, S., PALLAG, AM.,TOTH, I., KRUSPER, L., BRAUN, M., VICAS, L., Determination of Oligoelements Content of Plant Material and Assessment of Bioactive Compounds from Calendula officinalis Lyophilized Extract, Rev. Chim. (Bucharest), 68, no. 8, 2017, p.1786.

15. COPOLOVICI, L., TIMIS, D., TASCHINA, M., COPOLOVICI, D., CIOCA, G., BUNGAU, S., Diclofenac Influence on Photosynthetic Parameters and Volatile Organic Compounds Emision from Phaseolus vulgaris L.Plants, Rev. Chim. (Bucharest), 68, no. 9, 2017, p.2076. 16. MOLDAVAN, Z., Metode de monitorizare a substantelor toxice. Note de curs si aplicatii, Ed. Universitatii din Bucuresti, 2012.

17. DAVID,V., MEDVEDOVICl, A., Metode de separare si analiza cromatografica, editia a II-a, Ed. Universitatii din Bucuresti, 2008. 18.*** http://www.europeana.ro/dosare/mediu.htm. legislatie.

19. *** GHIDUL SG, Criterii ecologice pentru produse din piele si blanuri, 2004.

20. SEMENESCU, A., BABIS, C., IACOBESCU, G., ROGOBETE, M., RACUCIU, C., NEN, M., CHIVU, O.R., GHIMIS, S.S., Research on the Implementation of Cleaner Technologies for obtaining chemicals, in relation to the environment, Rev. Chim. (Bucharest), 68, no. 4, 2017, p.772. 
21. BALAU MANDRU, T., NICULESCU, O., PRUNEANU, M., MAIER, V., Product with antistatic-antifelting effect for fur treatment, Patent OSIM 127298/2014.

22. NICULESCU, O., TONEA, R.A., TONEA, S, Product for biological protection and fragrance of furs and fur garment, Patent Aplication OSIM A/00395/2014.

23. NICULESCU, O., LECA, M., MOLDOVAN, Z., DESELNICU, D.C., Obtaining and characterizing a product with antifungal properties based on essential oils and natural waxes for finishing natural leathers, Rev. Chim. (Bucharest), 66, no. 11, 2015, p.1733.
24. NICULESCU, O., LECA, M., MOLDOVAN, Z., DESELNICU, D.C., Research on obtaining products for fragrance and biological protection of natural leathers and furs, Rev. Chim. (Bucharest), 66, no. 12, 2015, p. 1956

Manuscript received: 14.09 .2018 